\title{
Research Article: Studies on genetic variability, heritability and genetic advance in lisianthus [Eustoma grandiflorum (Raf.) Shinners]
}

\section{K. ANITHA, V. JEGADEESWARI AND N. SELVARAJ}

Article Chronicle: Received :

11.07.2017;

Accepted :

24.07.2017

\section{KEY WoRds:}

Lisianthus, Variability, Heritability, Genetic advance

Author for correspondence :

\section{K. ANITHA}

Horticultural Research

Station (T.N.A.U.),

UDHAGAMANDALAM

(T.N.) INDIA

Email:anithasujay@

gmail.com

See end of the article for authors' affiliations
SUMMARY : The study was conducted on genetic variability, heritability, genetic advance and correlation co-efficient for vegetative and floral characters of 12 cultivars of Lisianthus which exhibited significant differences in all the characters studied. The cultivar Echo Pink exhibited maximum plant height $(93.43 \mathrm{~cm})$ and number of shoots per plant (5.27) during harvest, while minimum was observed in Echo Lavender $(51.86 \mathrm{~cm})$ and Shallot Green $(2.13)$. The co-efficient of variation was found to be higherin number of buds per plant $(\mathrm{GCV}=43.24, \mathrm{PCV}=43.60)$ and minimum for bud diameter $(\mathrm{GCV}=6.62$, PCV $=8.27)$. Heritability estimates were high for all the characters studied. The highest heritability was noticed for number of buds per plant $\left(h^{2}=98.35\right)$. High genetic advance as per cent mean was exhibited by number of buds per plant (88.35) while the minimum of 10.43 was noticed in bud diameter.High heritability coupled with high genetic advance was noted for traits namely days taken for bud initiation $\left(\mathrm{h}^{2}=98.20, \mathrm{GA}=39.86\right)$ and number of buds per plant $\left(\mathrm{h}^{2}=98.35, \mathrm{GA}=25.03\right)$ indicating the possible role of additive gene action which suggested that improvement of these traits would be effective for further selection of superior genotypes.

How to cite this article : Anitha, K., Jegadeeswari, V. and Selvaraj, N. (2017). Studies on genetic variability, heritability and genetic advance in lisianthus [Eustoma grandiflorum (Raf.) Shinners]. Agric. Update, Agric. Update, 12(TECHSEAR-2) : 471-474; DOI: 10.15740/HAS/AU/12.TECHSEAR(2)2017/471-474. 